\title{
Comparison of serum monocide chemoattractant protein levels with immunosuppressive therapy protocols in patients with renal transplantation
}

\author{
Demirci $\mathrm{R}^{1}$, Akyuz $\mathrm{O}^{2}$ \\ Department of Nephrology, University of Health Sciences Kanuni Sultan Suleyman Training \\ and Research Hospital, Turkey. rcpdemirci@windowslive.com
}

\begin{abstract}
BACKGROUND: Renal transplantation stands out with lower cost advantages in life expectancy, quality of life and especially in the long-term perspective compared to dialysis. Having significant side effects of immunosuppressive drugs in terms of patient and graft survival limits the use of these drugs. A variety of markers are being explored to prolong the renal graft life. One of these molecules, monocide chemoattractant protein (MCP-1) is a marker involved in renal inflammation. The production of MCP-1 was blocked in kidney diseases and the disease was improved. Along with these promising developments, we decided to investigate whether there is a significant relationship between immunosuppressive therapies used in renal transplantation therapy and serum MCP-1 levels.

METHODS: Our study was performed in 80 patients who underwent kidney transplantation followed in Haydarpaşa Numune Training and Research Hospital. These 80 patients were examined in 4 groups as Group 1 (cyclosporin), Group 2 (tacrolimus), Group 3 (sirolimus) and Group 4 (everolimus). Serum MCP-1 levels were compared between the groups by using ELISA method.

RESULTS: In our study, serum MCP-1 levels were significantly higher in cyclosporine and tacrolimus groups than in sirolimus $(p<0.05)$. When calcineurin inhibitors and everolimus were compared, it was not statistically significant, although calcineurin inhibitors were higher.

CONCLUSION: Understanding the role of MCP-1 in monocyte homeostasis and the effects of MCP-1 inhibition in kidney disease will help to design better diagnostic and treatment strategies in patients with inflammatory kidney disease (Tab. 2, Fig. 7, Ref. 45). Text in PDF www.elis.sk KEY WORDS: renal transplantation, monocide chemoattractant protein, immunosuppressive therapy protocols.
\end{abstract}

\begin{abstract}
Abbreviations: MCP-1 - monocide chemoattractant protein, ICAM-1 - intercellular adhesion molecule-1, VUR - vesicoureteral reflux, TIN - tubulointerstitial nephritis, GFR - glomerular filtration rate
\end{abstract}

\section{Introduction}

Chemokines are heparin-binding proteins that are structurally related to cytokines and whose main task is to control cell trafficking $(1,2)$. Today, more than 50 human chemokines and 20 G-protein-linked chemokine receptors have been described. Monocyte chemoattractant protein -1 (MCP-1) was one of the first chemokines identified and has been extensively studied in the past 30 years $(3,4)$.

${ }^{1}$ Department of Nephrology, University of Health Sciences Kanuni Sultan Suleyman Training and Research Hospital, Turkey, and ${ }^{2}$ Department of Nephrology, Bilecik State Hospital, Bilecik, Turkey

Address correspondence: R. Demirci, MD, Department of Nephrology, University of Health Sciences Kanuni Sultan Suleyman Training and Research Hospital, 34303 Kucukcekmece, Istanbul, Turkey.

Phone: +905422532422, Fax: +902124041500
Monocyte chemoattractant protein -1 (MCP-1/CCL2) is a member of the $\mathrm{C}-\mathrm{C}$ chemokine family and also potent chemotactic factor for monocytes. CCL2 is produced by many cells such as endothelial cells, fibroblasts, epithelial cells, smooth muscle cells, mesengial cells, astrocytic cells, monocytic and microglial cells (5-8). In the kidney, the types of cells that produce MCP-1 are tubular cells, smooth muscle cells, mesangial cells, podocytes, as well as eosinophils and mast cells (9). However, it is known that the main source of CCL2 are monocytes/macrophages (10). CCL2 monocytes regulate the migration and infiltration of memory $\mathrm{T}$ cells and NK cells.

Urinary MCP-1 excretion is significantly higher in patients with acute graft rejection than in patients with stable graft function. In addition, urinary excreted MCP-1 levels in humans and animals with kidney damage are correlated with albumin /protein excretion and the severity of renal damage $(11,12)$. Mesangial cell exposure to MCP-1 is known to cause an increase in intracellular expression of interstitial matrix molecules such as intercellular adhesion molecule-1 (ICAM-1) and fibronectin in inflammatory molecules $(13,14)$. MCP-1 stimulates IL-6 secretion and ICAM-1 synthesis in renal tubular epithelial cells (15). In addition, binding of MCP-1 
to CCR2 receptor in podocytes causes a significant reduction in mRNA and protein expressions in nephron to podocyte migration $(16,17)$. An example of the possible importance of MCP-1 as a biomarker is allograft rejection in kidney transplantation. MCP-1 localization is mostly found in the proximal tubular cells and infiltrating mononuclear cells of the transplanted kidney $(18,19)$.

There is an increasing amount of evidence to suggest that MCP-1 plays a role beyond a chemoattractant protein and directly affects other cell types in the kidney.

\section{Material and methods}

Our study was conducted at Haydarpaşa Numune Training and Research Hospital between January 2011 and November 2011. Eighty patients aged 18-65 years with creatinine level $2 \mathrm{mg} / \mathrm{dL}$ and below who underwent renal transplantation at least 6 months before visiting our Nephrology outpatient clinic were included in the study. Patients who used tacrolimus, cyclosporin, sirolimus and everolimus together with mycophenolate mofetil and steroids were included in the study as the primary immunosuppressive treatment for standardization. Patients were informed and approved and the study was started.

Patients in the study group were divided into 4 groups according to the drug groups they used, patients using calcineurin inhibitors, and those using cyclosporin (group 1), tacrolimus (group 2), and patients using m-TOR inhibitors, as sirolimus (group 3) and everolimus (group 4). Each group of patients using cyclosporine and tacrolimus included 25 patients and each group of patients using sirolimus and everolimus included 15 patients. Patients with serum drug levels in the reference range were included in the study. In these groups, hemoglobin, creatine, uric acid, 24-hour urine protein, creatinine clearance were compared by measuring MCP-1 levels.

Patients under 18 and over 65 years of age, patients with kidney transplant duration less than 6 months, patients with serum creatinin level $2 \mathrm{mg} / \mathrm{dl}$ and above, patients diagnosed with diabetes mellitus, patients with active infection with high CRP, patients with hepatitis, malignancy and chronic liver disease were excluded from the study.

In addition to biochemical blood tests, MCP-1 was detectedin all patients in our study. Blood samples taken for MCP-1 were stored at -80 degrees at $4000 \mathrm{rpm}$ until operation after 5 minutes of centrifugation. Complete blood counts of the patients were performed with the automatic SYSMEX X-E 2100 brand automatic blood count device. The protein level of the patients in the 24-hour urine was evaluated with the device named "ARHTECTC-1600". MCP-1 levels were studied by ELISA method with " DiaSorin ETİ-Max 3000 ' brand device.

For this study, approval of the Ethics Committee of Haydarpasa Numune Training and Research Hospital was obtained (the decision number HNEAH - KAEK 2011/KK/11).

\section{Statistical analysis}

One-way ANOVA (Variance analysis) test was used for statistical comparisons. Statistical significance between groups was evaluated by Post Hock LSD test. In the results, it was considered meaningful that the $\mathrm{p}$ value was below 0.05 . SPSS 22.0 version was used to analyze the data.

\section{Results}

There were a total of 40 male and 40 female participants in the study group. In the cyclosporine group, 16 of the patients were male, 9 were female, 10 of the tacrolimus patients were male, 15 were female, 5 of the sirolimus patients were male, 10 were female, and 9 of the everolimus group were female. In chronic renal failure etiology; hypertension was detected in 25 patients, glomerulonephritis in 15 patients, vesicoureteral reflux (VUR) in 8 patients, nephrolithiasis in 3 patients, pyelonephritis in 3 patients, tubulointerstitial nephritis (TIN) in 1 patient, and idiopathic renal failure in 25 patients (Fig. 1).

The average age in group 1 was $38.76 \pm 8.55$, the minimum value was 24 years old, and the maximum value was 59 years old. The average age in group 2 was $40.5 \pm 10.4$ years, the minimum value was 21 years old, and the maximum value was 60 years old. In group 3, the average age was $40.06 \pm 12.6$, the minimum value was 25 years old, and the maximum value was 63 years old. In group 4 , the average age was $37.20 \pm 10.87$, the minimum value was 18 years old, and the maximum value was 60 years old. There was no statistically significant difference between the groups in terms of age.

The mean and standard deviation values of hemoglobin were determined as $13.15 \pm 1.63 \mathrm{~g} / \mathrm{dl}$ in group $1,13.18 \pm 1.59 \mathrm{~g} / \mathrm{dl}$ in group $2,11.83 \pm 1.66 \mathrm{~g} / \mathrm{dl}$ in group 3 , and $11.93 \pm 2.25 \mathrm{~g} / \mathrm{dl}$ in group 4 . In terms of hemoglobin values, compared to the tacrolimus and cyclosporin group, the sirolimus and everolimus group were lower in the sirolimus and everolimus group $(\mathrm{p}<0.05)$ (Fig. 2).

Ferritin mean and standard deviation values were determined as $279.04 \pm 165.59 \mathrm{~g} / \mathrm{dL}$ in group $1,230.24 \pm 183.27 \mathrm{~g} / \mathrm{dL}$ in group

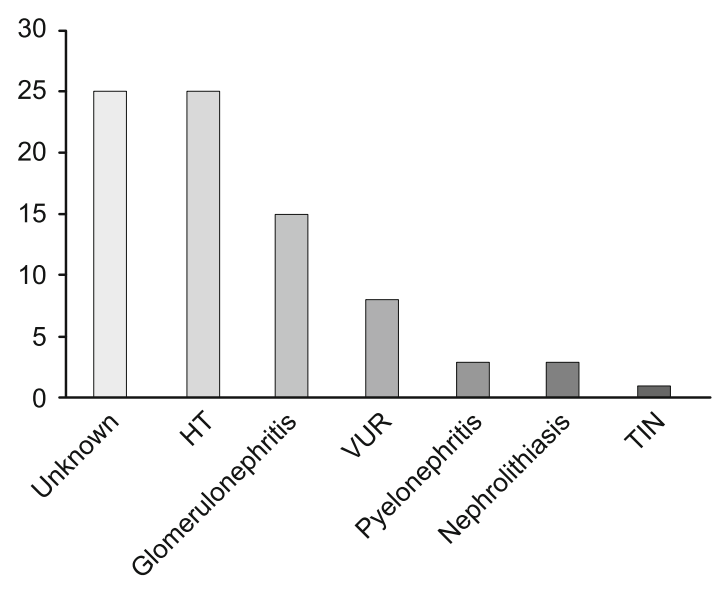

Fig. 1. Causes of chronic renal failure before kidney transplantation of patients. HT - hypertension, VUR - vesicoureteral reflux, TIN tubulointerstitial nephritis 
Tab. 1. Relationship between immunosuppressive agents used and biochemical parameters.

\begin{tabular}{|c|c|c|c|c|c|c|}
\hline & & & $\begin{array}{c}\text { Age } \\
\text { (year) }\end{array}$ & $\begin{array}{l}\text { Hemoglobin } \\
(\mathrm{g} / \mathrm{dL})\end{array}$ & $\begin{array}{l}\text { Ferritin } \\
(\mathrm{ng} / \mathrm{mL})\end{array}$ & $\begin{array}{c}\text { Uric acid } \\
(\mathrm{mg} / \mathrm{dL})\end{array}$ \\
\hline \multirow{4}{*}{$\stackrel{\mathscr{6} 0}{己}$} & $\begin{array}{l}\text { Cyclosporine } \\
\text { (group 1) }\end{array}$ & Mean \pm SD & $38.76 \pm 8.55$ & $13.15 \pm 1.63$ & $279.04 \pm 165.59$ & $7.26 \pm 1.62$ \\
\hline & $\begin{array}{l}\text { Tacrolimus } \\
\text { (grup 2) }\end{array}$ & Mean \pm SD & $40.52 \pm 10.41$ & $13.18 \pm 1.59$ & $230.24 \pm 183.27$ & $5.48 \pm 1.68$ \\
\hline & $\begin{array}{l}\text { Sirolimus } \\
\text { (grup 3) }\end{array}$ & Mean \pm SD & $40.06 \pm 12.87$ & $11.83 \pm 1.66$ & $248.66 \pm 157.04$ & $4.82 \pm 1.43$ \\
\hline & $\begin{array}{l}\text { Everolimus } \\
\text { (grup 4) }\end{array}$ & Mean \pm SD & $37.20 \pm 10.87$ & $11.93 \pm 2.25$ & $207.49 \pm 172.06$ & $5.54 \pm 1.70$ \\
\hline \multirow{5}{*}{ 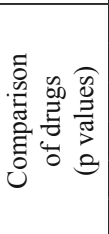 } & \multicolumn{2}{|c|}{ Tacrolimus - cyclosporine } & 0.552 & 0.962 & 0.316 & 0.001 \\
\hline & \multicolumn{2}{|c|}{ Tacrolimus - sirolimus } & 0.894 & 0.022 & 0.742 & 0.223 \\
\hline & \multicolumn{2}{|c|}{ Tacrolimus - everolimus } & 0.332 & 0.033 & 0.685 & 0.901 \\
\hline & \multicolumn{2}{|c|}{ Cyclosporine - sirolimus } & 0.702 & 0.024 & 0.588 & 0.001 \\
\hline & \multicolumn{2}{|c|}{ Cyclosporine - everolimus } & 0.648 & 0.037 & 0.512 & 0.002 \\
\hline
\end{tabular}

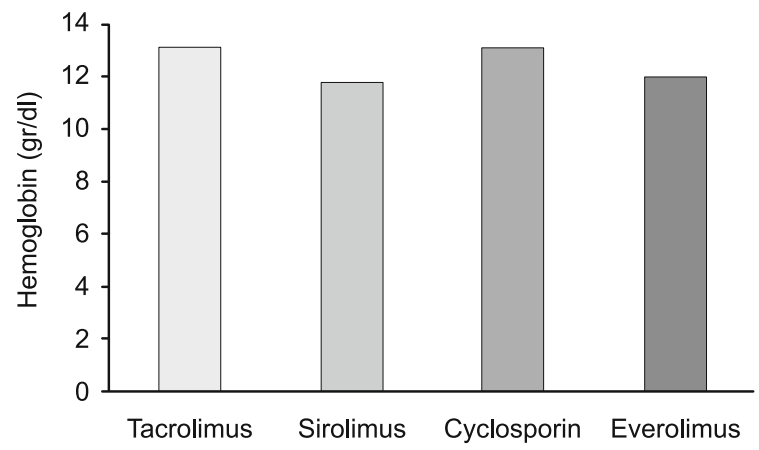

Fig. 2. Hemoglobin relationship with immunosuppressive drugs used.

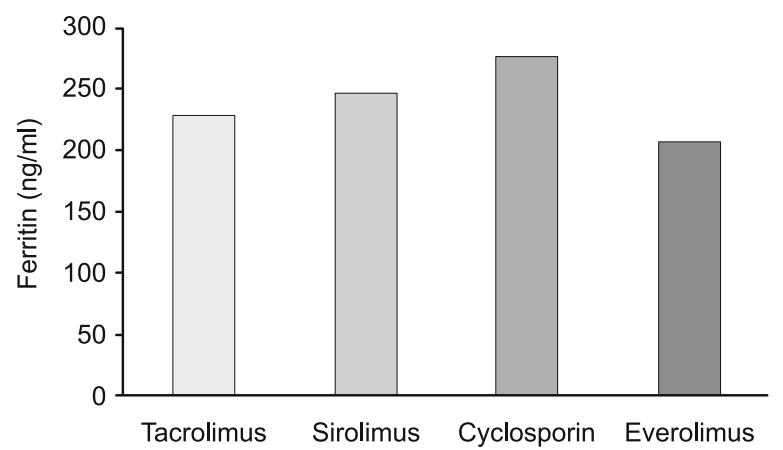

Fig. 3. Relationship between used immunosuppressive drugs and serum ferritin level.

$2,248.66 \pm 157.04 \mathrm{~g} / \mathrm{dL}$ in group 3, 207.49 $\pm 172.06 \mathrm{~g} / \mathrm{dL}$ in group 4. There was no significant difference between the groups for ferritin values ( $\mathrm{p}>0.05)$ (Fig. 3).

Serum creatinine levels were $1.39 \pm 0.31 \mathrm{mg} / \mathrm{dL}$ in group 1 , $1.23 \pm 0.30 \mathrm{mg} / \mathrm{dL}$ in group $2,1.24 \pm 0.47 \mathrm{mg} / \mathrm{dL}$ in group 3 , and $1.37 \pm 0.39 \mathrm{mg} / \mathrm{dL}$ in group 4 . There were no significant differences between the groups ( $p>0.05$ ) (Fig. 4).

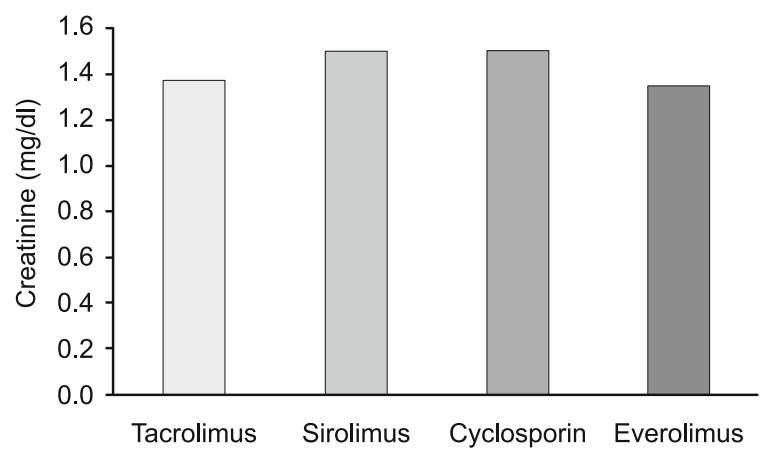

Fig. 4. Serum creatinine relationship with immunosuppressive drugs.

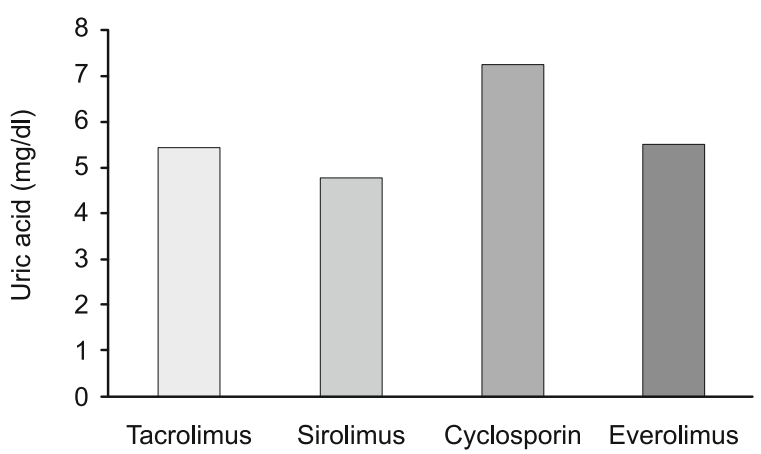

Fig. 5. Uric acid relationship with immunosuppressive drugs used.

Uric acid values were $7.26 \pm 1.62 \mathrm{mg} / \mathrm{dL}$ in group $1,5.48 \pm 1.68$ $\mathrm{mg} / \mathrm{dL}$ in group $2,4.82 \pm 1.43 \mathrm{mg} / \mathrm{dL}$ in group 3 , and $5.54 \pm 1.70$ $\mathrm{mg} / \mathrm{dL}$ in group 4 . Uric acid values in group 1 were significantly higher than in the other groups $(\mathrm{p}<0.01)$ (Fig. 5).

Protein values in 24-hour urine were $0.30 \pm 0.17 \mathrm{~g} /$ day in group $1,0.21 \pm 0.11 \mathrm{~g} /$ day in group $2,1.03 \pm 0,37 \mathrm{~g} /$ day in group 3 , and $0.87 \pm 0.77 \mathrm{~g} /$ day in group 4 . In group 2 , protein level in 
Tab. 2. Relationship between the immunosuppressive agents used and creatinine, glomerular filtration rate, 24-hour urine protein and MCP-1.

\begin{tabular}{|c|c|c|c|c|c|c|}
\hline & & & Creatinine (mg/dL) & $\begin{array}{l}\text { Glomerular filtration rate } \\
\left(\mathrm{ml} / \mathrm{min} / 1.73 \mathrm{~m}^{2}\right)\end{array}$ & $\begin{array}{l}\text { 24-hour urine protein } \\
\text { (g/gün) }\end{array}$ & $\begin{array}{l}\text { MCP-1 } \\
\text { (ng/dL) }\end{array}$ \\
\hline \multirow{4}{*}{ 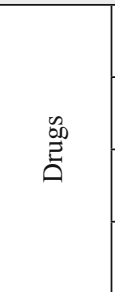 } & $\begin{array}{l}\text { Cyclosporine } \\
\text { (group 1) }\end{array}$ & Mean \pm SD & $1.39 \pm 0.31$ & $64.48 \pm 18.87$ & $0.30 \pm 0.17$ & $343.40 \pm 155.43$ \\
\hline & $\begin{array}{l}\text { Tacrolimus } \\
\text { (grup 2) }\end{array}$ & Mean \pm SD & $1.23 \pm 0.11$ & $66.16 \pm 14.95$ & $0.21 \pm 0.11$ & $354.52 \pm 152.74$ \\
\hline & $\begin{array}{l}\text { Sirolimus } \\
\text { (grup 3) }\end{array}$ & Mean $\pm \mathrm{SD}$ & $1.24 \pm 0.47$ & $67.13 \pm 15.59$ & $1.03 \pm 0.37$ & $197.13 \pm 101.37$ \\
\hline & $\begin{array}{l}\text { Everolimus } \\
\text { (grup 4) }\end{array}$ & Mean $\pm \mathrm{SD}$ & $1.37 \pm 0.39$ & $65.33 \pm 18.07$ & $0.87 \pm 0.77$ & $267.33 \pm 121.74$ \\
\hline \multirow{5}{*}{ 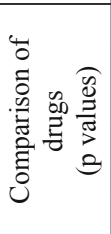 } & \multicolumn{2}{|c|}{ Tacrolimus - cyclosporine } & 0.128 & 0.727 & 0.653 & 0.780 \\
\hline & \multicolumn{2}{|c|}{ Tacrolimus - sirolimus } & 0.935 & 0.861 & 0.001 & 0.001 \\
\hline & \multicolumn{2}{|c|}{ Tacrolimus - everolimus } & 0.271 & 0.882 & 0.005 & 0.060 \\
\hline & \multicolumn{2}{|c|}{ Cyclosporine - sirolimus } & 0.215 & 0.634 & 0.002 & 0.002 \\
\hline & \multicolumn{2}{|c|}{ Cyclosporine - everolimus } & 0.823 & 0.878 & 0.013 & 0.100 \\
\hline
\end{tabular}

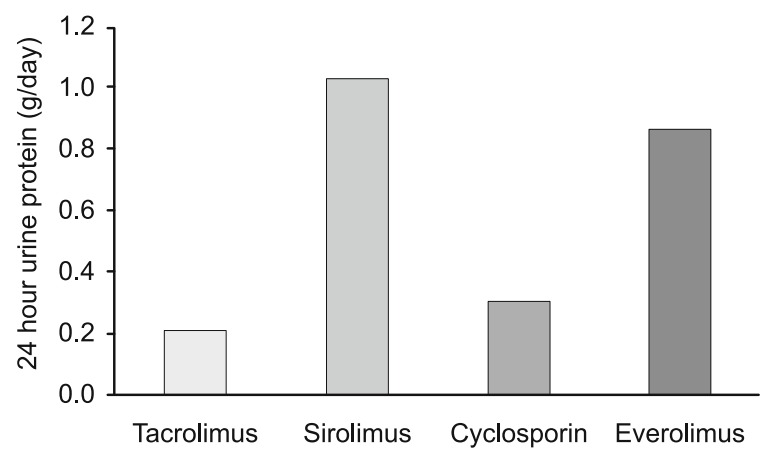

Fig. 6. Protein relationship in 24-hour urine with immunosuppressive drugs.

urine was significantly lower than in the other groups $(\mathrm{p}<0.05)$ (Fig. 6).

Serum MCP-1 values were $343.40 \pm 155.43 \mathrm{ng} / \mathrm{dL}$ in group 1, $354.52 \pm 152.74 \mathrm{ng} / \mathrm{dL}$ in group $2,197.13 \pm 101.37 \mathrm{ng} / \mathrm{dL}$ in group 3 , and $267.33 \pm 121.74 \mathrm{ng} / \mathrm{dL}$ in group 4 (Tab. 2 ). When group 1 and group 2 were compared statistically with group 3, MCP-1 values of group 1 and group 2 were significantly higher $(\mathrm{p}<0.05)$. When group 1 and group 2 were compared statistically with group 4, MCP-1 values of group 1 and group 2 were still high, although they were not significant ( $\mathrm{p}>0.05$ ) (Fig. 7).

\section{Discussion}

Dramatic improvements in renal allograft survival rates were achieved with the introduction of calcineurin inhibitors to clinical use in renal transplantation in 1983. Two immunosuppressive agents in this group, cyclosporin and tacrolimus inhibit $\mathrm{T}$ cell activation by inhibiting calcineurin. Calcineurin is a cytoplasmic phosphatase whose expression increases when there is antigen presentation to T cells and is essential for the transcription of IL-2 and other cytokines. Despite its beneficial effects on graft survival,

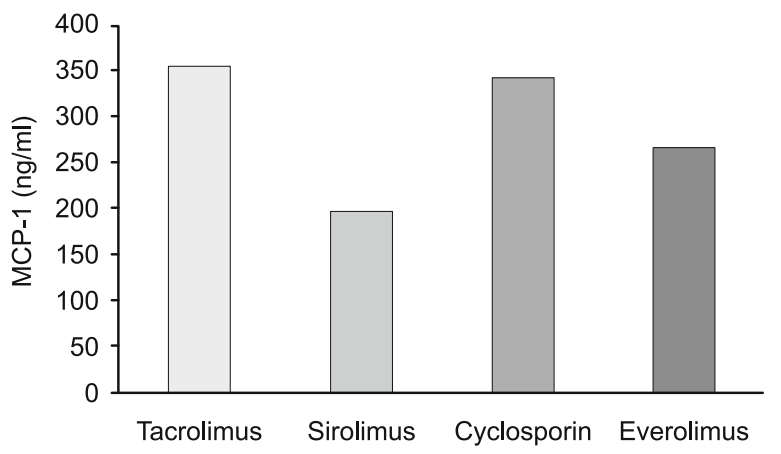

Fig. 7. MCP-1 relationship with immunosuppressive drugs used.

calcineurin inhibitors have many side effects such as nephrotoxicity, hypertension, hyperlipidemia, glucose intolerance, hirsutism and gingival hypertrophy. In clinical practice, the most important of these side effects is nephrotoxicity due to calcineurin inhibitor use $(20,21)$. Calcineurin inhibitor nephrotoxicity can be seen even at normal serum drug levels and the diagnosis of toxic damagerelated renal damage can only be made by biopsy. In addition, renal function tests, especially in chronic toxicity, may not correlate with histopathological findings. Therefore, new biomarkers are needed in the follow-up of patients using calcineurin inhibitor group.

Sirolimus and everolimus (m-TOR inhibitors) have been used to prevent rejection in solid organ transplants (22). This group of drugs target signal transduction pathways in the cell cycle, thereby inhibiting interleukin-2-induced $\mathrm{T}$ cell proliferation.

MCP-1 is the most studied member of the chemokine family. It is thought to be a potential intervention point in the treatment of many diseases such as multiple sclerosis, rheumatoid arthritis, atherosclerosis and insulin resistant diabetes (23-26). MCP1 was first detected and identified in membranous nephropathy, IgA nephropathy, and glomerulosclerosis. MCP-1 staining was stronger in tubular epithelial cells and correlated with interstitial 
infiltration of macrophages (27). Since then, detection of MCP-1 in kidney tissues and urine samples has been investigated in various kidney diseases.

The main inducers of MCP-1 expression are IL-1, tumor necrosis factor alpha and interferon gamma, but other cytokines or growth factors such as IL-4, M-CSF (colony stimulating factors), GM-CSF, platelet-derived growth factor, transformation like other cytokines. Growth factor-beta (TGF-b) can also induce lipopolysaccharides, reactive oxygen species and immune complexes MCP-1.

Suppressors of MCP-1 are anti-inflammatory molecules, especially retinoic acid and glucocorticoids (28).

Locally produced MCP-1 is thought to be particularly effective in the onset and progression of tubulointerstitial diseases. This finding was revealed by experimental studies with mice lacking MCP-1. When nephritic syndrome-induced nephritic mice were separated and compared as mcp-1 (-) and wild type, MCP-1 (-) mice showed fewer tubulointerstitial lesions but no difference in glomerular lesions (29). However, studies have found that in inflammatory or non-inflammatory glomerular injuries, the expression of glomerular MCP-1 correlates with glomerular damage $(30,31)$. Therefore, it can be said that MCP-1 has an effect on glomerular diseases.

MCP-1 plays a key role in the activation and chemotaxis of macrophages. T-lymphocytes act as mediators for kidney tissue damage. Therefore, it is thought to be the function of MCP-1 in many renal pathologies. In the study of Tesch et al, it was observed that when MCP-1 (-) and MCP-1 (+) formed experimental nephrotoxic serum nephritis in mice, there was no difference in the severity of glomerular lesions with less tubular damage and macrophage infiltration in mice with MCP-1 (-) (29). It was emphasized that strategies for elimination of MCP-1 in tubulointerstitial kidney diseases can be protective against the progressive loss of tubules. In another study, it was reported that MCP-1 plays an active role in the formation of glomerular damage as well as tubulointerstitial damage $(30,31)$. Interestingly, in patients with cresentic glomerulonephritis, MCP-1 is not only released from leukcocytes that infiltrate tubular epithelial cells and tubulointersitus, but also from cresents and parietal epithelium (32).

In addition to its release from mesengial cells, other sources of MCP-1 in urine are endothelial cells, mononuclear cells $(33,34)$ and tubular epithelial cells $(34,35)$. Increasing MCP-1 production by tubular cells may be due to inducing by cytokines $(36,37)$ and exposure to urinary proteins (38). In both cases it is the mediator of progressive renal damage (39).

In the nephrotoxicity of calcineurin, especially in its chronic form, patchy fibrosis and its accompanying tubular atrophy dominate the histopathological picture. In this study, MCP-1 levels were found to be higher in patients using one of the calcineurin inhibitors than in other patients. This suggests that MCP-1 may play an active role in tubulointerstitial damage caused by calcineurin nephrotoxicity. In experimental studies, anti MCP-1 antibodies have been shown to reduce proteinuria in cresentic glomerulonephritis, reduce glomerulosclerosis, and improve renal function (40).
It is known that cyclosporine decreases renal blood flow by vasoconstriction in afferent and efferent arterioles, thereby reducing the rate of glomerular filtration (41). Interestingly, the renal vascular tonus induced by cyclosporin does not decrease over time. Temporary reductions in renal plasma flow and glomerular filtration rate are correlated with plasma serum peak cyclosporin levels reached two to four hours after drug dosage and drug administration (42). In other words, calcineurin toxicity can be said to be associated with recurrent episodes of ischemia reperfusion.

It has been reported in different studies that MCP-1 plays an important role in the physiopathogenesis of ischemia-reperfusion injury. Furuichi et al. demonstrated that after generating ischemia-reperfusion experimentally in mice, cell infiltration and ischemia-reperfusion injury were less developed in MCP-1 (-) mice compared to the severity of damage. In the same study, inhibition of CCR2, the receptor of MCP-1, was shown to significantly reduce inflammatory cell infiltration and prevent tubule necrosis in the case of renal ischemia reperfusion. In addition, ischemia-reperfusion damage is known to be associated with long-term graft functions (42). The probable cause of the increase in MCP-1 levels observed in patients using calcineurin inhibitors in our study was chronic ischemia-reperfusion damage caused by these agents.

Inhibition of CCR2, the receptor of MCP-1 as previously mentioned, has been shown to significantly reduce inflammatory cell infiltration and prevent tubule necrosis in the case of renal ischemia reperfusion. Together with the data from our study, it can be speculated that inhibiting the effects of MCP-1 may help in the prevention and/or treatment of nephrotoxicity due to calcineurin use.

MCP-1 appears to be a key player in the pathogenesis of inflammatory kidney disease. It also regulates the inflammatory response in kidney disease. MCP-1 affects the whole monocyterelated cascade, creating a chemokine gradient for inflammation, adhesion and infiltration resulting from the release of monocytes from the bone marrow. As a result, monocytes and macrophages in the kidney cause differentiation as a result of stimulation (43-45).

As a result, calcineurin inhibitors are still the most effective and intensely used immunosuppressive agents in renal transplantation. However, in clinical practice, adequate progress has not been achieved in the follow-up, prevention and treatment of nephrotoxicity, the most feared side effect of these agents. Our study suggests that MCP-1 may play a key role in the follow-up and treatment of nephrotoxicity due to calcineurin inhibitors. However, there is a need for studies where MCP-1 levels can be evaluated together with biopsy findings.

\section{Conclusions}

1. In our study, no significant difference was found between the groups in terms of age.

2. Hb values were compared between groups. Hb value was significantly lower in M-TOR inhibitors $(\mathrm{p}<0.05)$. 
3. Serum uric acid levels were significantly higher in cyclosporine than other drugs $(\mathrm{p}<0.05)$.)

4. Significant elevation in proteinuria level was detected with M-TOR inhibitors when proteinuria was compared between the groups.

5. Serum MCP-1 levels were significantly higher in the cyclosporine and tacrolimus group compared to sirolimus $(\mathrm{p}<0.05)$. When calcineurin inhibitors were compared with everolimus, it was found to be higher in calcineurin inhibitors, but it was not found statistically significant $(\mathrm{p}>0.05)$.

\section{References}

1. Wu VY, Walz DA, McCoy LE. Purification and characterization of human and bovine platelet factor 4. Preparat Biochem 1977; 7 (6): 479-493.

2. Proudfoot AE. Chemokines and glycosaminoglycans. Front Immunol 2015; 6: 246

3. Baggiolini M, Loetscher $\mathbf{P}$. Chemokines in inflammation and immunity. Immunol Today 2000; 21: 418-420.

4. Kim MJ, Tam FWK. Urinary monocyte chemoattractant protein-1 in renal disease. Clin Chim Acta 2011; 412: 2022-2030.

5. Cushing SD, Berliner JA, Valente AJ, Territo MC, Navab M, Parhami F, Gerrity R, Schwartz CJ, Fogelman AM. Minimally modified low density lipoprotein induces monocyte chemotactic protein 1 in human endothelial cells and smooth muscle cells. Proc Natl Acad Sci USA 1990; 87: 5134-5138.

6. Standiford TJ, Kunkel SL, Phan SH, Rollins BJ, Strieter RM. Alveolar macrophage-derived cytokines induce monocyte chemoattractant protein-1 expression from human pulmonary type II-like epithelial cells. J Biol Chem 1991; 266: 9912-9918.

7. Brown Z, Strieter RM, Neild GH, Thompson RC, Kunkel SL, Westwick J. IL-1 receptor antagonist inhibits monocyte chemotactic peptide 1 generation by human mesangial cells. Kidney Int 1992; 42: 95-101.

8. Barna BP, Pettay J, Barnett GH, Zhou P, Iwasaki K, Estes ML. Regulation of monocyte chemoattractant protein-1 expression in adult human non-neoplastic astrocytes is sensitive to tumor necrosis factor (TNF) or antibody to the 55-kDa TNF receptor. J Neuroimmunol 1994; 50: 101-107.

9. Yadav A, Saini V, Arora S. MCP-1: chemoattractant with a role beyond immunity: a review. Clin Chim Acta 2010; 411: 1570-1579.

10. Yoshimura T, Yuhki N, Moore SK, Appella E, Lerman MI, Leonard EJ. 1989b. Human monocyte chemoattractant protein-1 (MCP-1). Full-length cDNA cloning, expression in mitogen- stimulated blood mononuclear leukocytes, and sequence similarity to mouse compete

11. Rovin BH, Doe N, Tan LC. Monocyte chemoattractant protein-1 levels in patients with glomerular disease. Am J Kidney Dis 1996; 27: 640-646.

12. Stephan M, Conrad S, Eggert $\mathbf{T}$ et al. Urinary concentration and tissue messenger RNA expression of monocyte chemoattractant protein-1 as an indicator of the degree of hydronephrotic atrophy in partial ureteral obstruction. J Urol 2002; 167: 1497-1502.

13. Giunti S, Pinach S, Arnaldi L et al. The MCP-1/CCR2 system has direct proinflammatory effects in human mesangial cells. Kidney Int 2006; 69: 856-863.

14. Giunti S, Tesch GH, Pinach S et al. Monocyte chemoattractant protein-1 has prosclerotic effects both in a mouse model of experimental diabetes and in vitro inhuman mesangial cells. Diabetologia 2008; 51: 198-207.
15. Viedt C, Dechend R, Fei J et al. MCP-1 induces inflammatory activation of human tubular epithelial cells: involvement of the transcription factors, nuclear factor kappaB and activating protein-1. J Am Soc Nephrol 2002; 13: 1534-1547.

16. Burt D, Salvidio G, Tarabra $\mathbf{E}$ et al. The monocyte chemoattractant protein-1/cognate $\mathrm{CC}$ chemokine receptor 2 system affects cell motility in cultured human podocytes. Am J Pathol 2007; 171: 1789-1799.

17. Tarabra E, Giunti S, Barutta F et al. Effect of the monocyte chemoattractant protein-1/CC chemokine receptor 2 system on nephrin expression in streptozotocin-treated mice and human cultured podocytes. Diabetes 2009; 58: 2109-2118.

18. Grandaliano G, Gesualdo L, Ranieri E et al. Monocyte chemotactic peptide-1expression and monocyte infiltration in acute renal transplant rejection. Transplantation 1997; 63: 414-420.

19. Prodjosudjadi W, Daha MR, Gerritsma JSJ et al. Increased urinary excretion of monocyte chemoattractant protein-1 during acute renal allograft rejection. Nephrol Dial Transplant 1996; 11: 1096-1103.

20. Pascual M, Theruvath T, Kawai T, Tolkoff-Rubin N, Cosimi A. Strategies to improve long-term outcomes after renal transplantation. N Engl J Med 2002; 346 (5): 580-590.

21. Pascual J, Perez-Saez M, Mir M, Crespo M. Chronic renal allograft injury: Early detection, accurate diagnosis and management. Transplant Rev (Orlando) 2012; 26: 280-290

22. Rostaing L, Kamar N. mTOR inhibitor/proliferation signal inhibitors: entering or leaving the field? J Nephrol 2010; 23: 133-42

23. Sorensen TL, Ransohoff RM, Strieter RM, Sellebjerg F. Chemokine CCL2 and chemokine receptor CCR2 in early active multiple sclerosis. Eur J Neurol 2004; 11: 445-449.

24. Hayashida K, Nanki T, Girschick H, Yavuz S, Ochi T, Lipsky PE. Synovial stromal cells from rheumatoid arthritis patients attract monocytes by producing MCP-1 and IL-8. Arthritis Res 2001; 3: 118-126.

25. Kusano KF, Nakamura K, Kusano H, Nishii N et al. Signifi cance of the level of monocyte chemoattractant protein-1 in human atherosclerosis. Circ J 2004; 68: 671-676.

26. Sartipy P, Loskutoff DJ. Monocyte chemoattractant protein 1 in obesity and insulin resistance. Proc Natl Acad Sci USA 2003; 100 : $7265-7270$

27. Prodjosudjadi W, Gerritsma JS, van Es LA et al. Monocyte chemoattractant protein-1 in normal and diseased human kidneys: an immunohistochemical analysis. Clin Nephrol 1995; 44: 148-155.

28. Haller H, Bertram A, Nadrowitz F, Menne J. Monocyte chemoattractant protein-1 and the kidney. Curr Opinion Nephrol Hypertens 2016; 25 (1): 42-49.

29. Tesch GH, Schwarting A, Kinoshita K et al. Monocyte chemoattractant protein-1 promotes macrophage-mediated tubular injury, but not glomerular injury, in nephrotoxic serum nephritis. J Clin Invest 1999; 103: $73-80$

30. Panzer U, Thaiss F, Zahner G et al. Monocyte chemoattractant protein-1 and osteopontin differentially regulate monocytes recruitment in experimental glomerulonephritis. Kidney Int 2001; 59: 1762-1769

31. Taal MW, Zandi-Nejad K, Weening B et al. Proinflammatory gene expression and macrophage recruitment in the rat remnant kidney. Kidney Int 2000; 58: 1664-1676

32. Segerer S, Cui Y, Hudkins KL et al. Expression of the chemokine monocyte chemoattractant protein-1 and its receptor chemokine receptor 
2 in human crescentic glomerulonephritis. J Am Soc Nephrol 2000; 11: $2231-2242$

33. Baggiolini M, Dewald B, Moser B. Interleukin-8 and related chemotactic cytokines: CXC and CC chemokines. Adv Immunol 1994; 55: 97-179

34. Wada T, Furuichi K, Sakai N et al. Up-regulation of monocyte chemoattractant protein-1 in tubulointerstitial lesions of human diabetic nephropathy. Kidney Int 2000; 58: 1492-1499

35. Mezzano SA, Barria M, Droguett MA et al. Tubular NF-kB and AP-1 activation in human proteinuric renal disease. Kidney Int 2001; 60: $1366-1377$

36. Prodjosudjadi W, Gerritsma JS, Klar-Mohamad N et al. Production and cytokine-mediated regulation of monocyte chemoattractant protein-1 by human proximal tubular epithelial cells. Kidney Int 1995; 48: 1477-1486

37. Gerritsma JS, van Kooten C, Gerritsen AF et al. Transforming growth factor-beta 1 regulates chemokine and complement production by human proximal tubular epithelial cells. Kidney Int 1998; 53: 609-616

38. Wang Y, Rangan GK, Tay YC et al. Induction of monocyte chemoattractant protein- 1 by albumin is mediated by nuclear factor $\mathrm{kB}$ in proximal tubule cells. J Am Soc Nephrol 1999; 10: 1204-1213
39. Remuzzi G, Bertani T. Pathophysiology of progressive nephropathies. N Engl J Med 1998; 339: 1448-1456

40. Wada T, Yokoyama H, Furuichi K et al. Intervention of crescentic glomerulonephritis by antibodies to monocyte chemotactic and activating factor (MCAFuMCP-1). FASEB J 1996; 10: 1418-1425

41. Lanese DM, Conger JD. Effects of endothelin receptor antagonist on cyclosporine-induced vasoconstriction in isolated rat renal arterioles. J Clin Invest 1993; 91: 2144.

42. Ruggenenti P, Perico N, Mosconi L et al. Calcium channel blockers protect transplant patients from cyclosporine-induced daily renal hypoperfusion. Kidney Int 1993; 43: 706.

43. de Zeeuw D, Agarwal R, Amdahl M et al. Selective vitamin D receptor activation with paricalcitol for reduction of albuminuria in patients with type 2 diabetes (VITAL study): a randomised controlled trial. Lancet 2010; 376: 1543-1551.

44. You H, Gao T, Cooper TK et al. Macrophages directly mediate diabetic renal injury. Am J Physiol Renal Physiol 2013; 305: F1719-F1727.

45. Lee S, Huen S, Nishio $\mathbf{H}$ et al. Distinct macrophage phenotypes contribute to kidney injury and repair. J Am Soc Nephrol 2011; 22: 317-332.

Received August 2, 2020. Accepted September 15, 2020. 